\title{
R Factors Conferring Resistance to Trimethoprim but not Sulphonamides
}

\author{
By R. W. HEDGES AND NAOMI DATTA \\ Department of Bacteriology, Royal Postgraduate Medical School, \\ Du Cane Road, London, WI2 oHS \\ AND M. P. FLEMING \\ Wellcome Veterinary Research Station, Frant, Kent
}

(Received 19 June 1972; revised 8 July 1972)

$\mathrm{R}$ factors conferring high-level resistance to trimethoprim and sulphonamides were identified in bacteria causing infections in patients at three London hospitals in I97I (Fleming, Datta \& Grüneberg, 1972). All were members of the W compatability group and came from the Camden area (Datta \& Hedges, 1972).

In April 1972 strains of Escherichia coli highly resistant to trimethoprim were isolated from calves at Frant, Kent, which is about 30 miles from the Camden area of London. The calves had been treated with large doses of a trimethoprim-sulphonamide preparation (Fleming, in preparation). The trimethoprim-resistant strains had various patterns of multiple drug resistance (always including resistance to sulphonamides) and from them various $\mathrm{R}$ factors were transferred to $E$. coli $\mathrm{KI} 2$. Trimethoprim resistance was transferred with resistance to streptomycin, separately from resistance to sulphonamides or other drugs. Methods were as described previously (Fleming et al. 1972).

An example of the trimethoprim-streptomycin resistance factors (R483) was studied in strains of Escherichia coli KI 2. Methods were as described by Datta \& Hedges (1972) and by Coetzee, Datta \& Hedges (1972).

\section{Phenotype of trimethoprim-streptomycin $R$ factors}

$\mathrm{R} 483$ and all other trimethoprim-streptomycin resistance factors tested were $f^{-}$. $\mathrm{R}_{483}$ was therefore tested for compatability with all known classes of $f i^{-} \mathrm{R}$ factors.

In all transfers where the recipient was streptomycin-sensitive, exconjugants that had acquired trimethoprim resistance also acquired streptomycin resistance. Thus the two determinants are presumably markers of a single plasmid.

Like W plasmids, which confer resistance to trimethoprim (Fleming et al. 1972; Datta \& Hedges 1972), R483 determined resistance to $>1000 \mu \mathrm{g} / \mathrm{ml}$ of the drug. As well as streptomycin resistance, $\mathrm{R} 483$ conferred resistance to spectinomycin (Hedges, $1972 b$ ).

\section{Compatibility of $R_{483}$}

The frequency of transfer of R 483 from Escherichia coli KI 2 SCI 6 to J53 with and without $\mathrm{R}$ factors of the various compatibility groups is given in Table I. R483 was compatible with all these, and therefore belonged to a new group, which we designate $\mathbf{B}$.

Although $\mathrm{R}_{300}$ and $\mathrm{R}_{4} 83$ are compatible (i.e. co-exist stably in KI2), the presence of either in a recipient reduces the frequency of transfer of the other (Table $I$ ). 


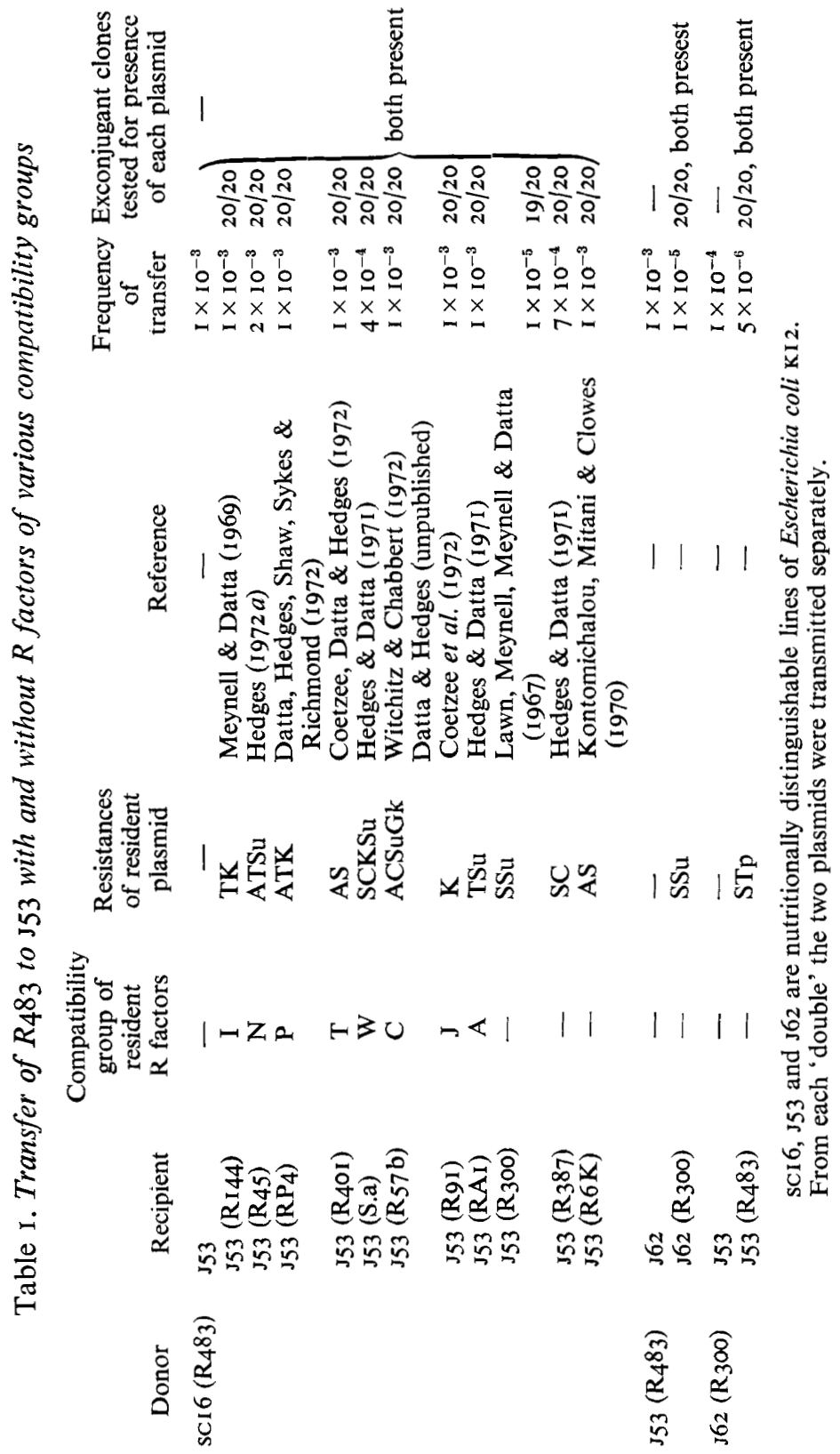


W plasmids which confer trimethoprim resistance also confer resistance to sulphonamides (Datta \& Hedges, 1972). These two synthetic drugs both affect folic acid metabolism. Trimethoprim is always used in conjunction with sulphonamide in human and veterinary medicine and thus any bacterium which acquires trimethoprim resistance is at no selective advantage unless it is also sulphonamide-resistant. However, sulphonamide resistance is fairly common in Escherichia coli, and all the calf E. coli strains carrying trimethoprimstreptomycin resistance factors also carried other $\mathbf{R}$ factors conferring sulphonamide resistance.

Since $\mathrm{R} 483$ was compatible with $\mathrm{R}$ factors of all the compatibility classes so far described we designate it the prototype of a new class, $B$. The exclusion of $R_{4} 83$ by $R_{300}$ and vice versa, although the two are compatible, contrasts with previous reports, where exclusion of one plasmid by another has usually been associated with incompatibility (Watanabe, I969). W plasmids, on the other hand, exert little if any exclusion; the resident plasmid is eliminated by entry of an incompatible replicon (Hedges \& Datta, 1971).

Trimethoprim is a newly introduced, synthetic antibacterial drug used in human medicine for 3 to 4 years (Garrod, 1969) and in veterinary medicine for a shorter time. Although bacteria have been exposed to the drug for so short a time, two independent $\mathrm{R}$ factor classes have emerged, conferring trimethoprim resistance.

\section{REFERENCES}

Coetzee, J. N., Datta, N. \& Hedges, R. W. (1972). Proteus rettgeri R factors. Journal of General Microbiology 72, 543-552.

DATTA, N. \& HeDGes, R. W. (1972). Trimethoprim resistance conferred by W plasmids in Enterobacteriaceae. Journal of General Microbiology 72, 349-355.

Datta, N., Hedges, R. W., Shaw, E., Sykes, R. B. \& Richmond, M. H. (I97I). Properties of an R factor from Pseudomonas aeruginosa. Journal of Bacteriology Io8, I244-I 249.

Fleming, M. P., DAtTA, N. \& GRÜNeberG, R. N. (1972). Trimethoprim resistance determined by R factors. British Medical Journal i, 726-728.

Garrod, L. P. (1969). The possible scope of trimethoprim-sulphonamide treatment. Postgraduate Medical Journal, Suppl. 45, 52-55.

Hedges, R. W. (1972a). Phenotypic characterization of $f^{-} \mathrm{R}$ factors determining the restriction and modification hsp II specificity. Molecular and General Genetics II5, 225-233.

HeDGes, R. W. $(1972 b)$. Resistance to spectinomycin determined by $\mathrm{R}$ factors of various compatibility groups. Journal of General Microbiology 72, 407-409.

Hedges, R. W. \& Datta, N. (I97I). $f^{-}$R factors giving chloramphenicol resistance. Nature, London 234 , 220-22I.

Kontomichalou, P., Mitani, M. \& Clowes, R. C. (1970). Circular R-factor molecules controlling penicillinase synthesis, replicating in Escherichia coli under either relaxed or stringent control. Journal of Bacteriology 105, 34-44.

Lawn, A. M., Meynell, E., Meynell, G. G. \& Datta, N. (1967). Sex pili and the classification of sex factors in the enterobacteriaceae. Nature, London 216, 343-346.

Meynell, E. \& Datta, N. (1969). Sex factor activity of drug-resistance factors. In Bacterial Episomes and Plasmids, pp. I20-I33. Edited by G. E. W. Wolstenholme and M. O'Connor. Ciba Symposium. London: J. \& A. Churchill.

Watanabe, T. (I969). Transferable drug resistance: the nature of the problem. In Bacterial Episomes and Plasmids, pp. 8I-97. Edited by G. E. W. Wolstenholme and M. O'Connor. Ciba Symposium. London: J. \& A. Churchill.

Witchitz, J. L. \& Chabbert, Y. A. (1972). Résistance transferable à la gentamicine. II Transmission et liasions du caractère de résistance. Annales de l'Institut Pasteur 122, 367-378. 